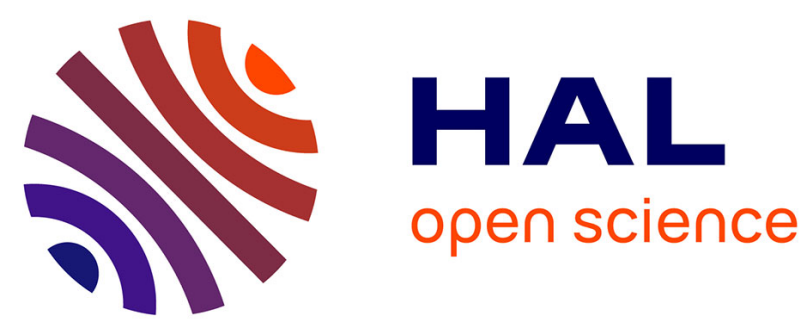

\title{
INFRARED VIBRATIONAL SPECTRA OF CHLORINATED AND HYDROGENATED AMORPHOUS SILICON
}

\author{
S. Kalem, Jacques Chevallier, S. Al Dallal, J. Bourneix
}

\section{- To cite this version:}

S. Kalem, Jacques Chevallier, S. Al Dallal, J. Bourneix. INFRARED VIBRATIONAL SPECTRA OF CHLORINATED AND HYDROGENATED AMORPHOUS SILICON. Journal de Physique Colloques, 1981, 42 (C4), pp.C4-361-C4-363. 10.1051/jphyscol:1981477 . jpa-00220934

HAL Id: jpa-00220934

https://hal.science/jpa-00220934

Submitted on 1 Jan 1981

HAL is a multi-disciplinary open access archive for the deposit and dissemination of scientific research documents, whether they are published or not. The documents may come from teaching and research institutions in France or abroad, or from public or private research centers.
L'archive ouverte pluridisciplinaire $\mathbf{H A L}$, est destinée au dépôt et à la diffusion de documents scientifiques de niveau recherche, publiés ou non, émanant des établissements d'enseignement et de recherche français ou étrangers, des laboratoires publics ou privés. 


\title{
INFRARED VIBRATIONAL SPECTRA OF CHLORINATED AND HYDROGENATED AMORPHOUS SILICON
}

\author{
S. Kalem, J. Chevallier, S. Al Dallal and J. Bourneix
}

Laboratoire de Physique des Solides, C.N.R.S., 1, place Amistide Briand, 92190 Meudon-Bellevue, France

\begin{abstract}
The infrared spectra of chlorinated and hydrogenated amorphous silicon have been measured. In addition to the hydrogen induced bands at 2110 , $1990,885,840$ and $640 \mathrm{~cm}^{-1}$, we observe two new modes at $545 \mathrm{~cm}^{-1}$ ( $\mathrm{Si}-\mathrm{C} 1$ stretching) and $500 \mathrm{~cm}^{-1}$ ( $S_{i}$ To modes induced by chlorine). Observation of the $545 \mathrm{~cm}^{-1}$ band proves that chlorine acts as a dangling bond terminator. Upon annealing, some of the Si-Cl groups transform into SiC14 molecules ( $\mathrm{SiCl}_{4}$ stretching at $615 \mathrm{~cm}^{-1}$ ). A good agreement is found between the total amount of chlorine determined by electron microprobe analysis and the value estimated from the integrated strength of the Si-Cl stretching mode.
\end{abstract}

Introduction :

A great deal of attention has been given in the past to hydrogenated amorphous silicion because of its potential application as a solar cell material $/ \overline{1} \bar{T} / \overline{2} \bar{T}$. More recently, SHIMADA et al. established that fluorine is able to compensate the dangling bonds as hydrogen does $/ \overline{3} \bar{T}$. Moreover, MADAN has shown that addition of fluorine in phosphorus doped matérials results in a higher doping efficiency and a lower resistivity never achieved in hydrogenate $\rfloor$ amorphous silicon $/ 47$.

other halogens can be imagined as dangling bond terminators. Horever, nothing has been reported until now about the role of chlorine in an amorpinous silicon matrix. In this paper, we report infrared absorption measurements in chlorinated and hydrogenated amorphous silicon ( $\mathrm{a}-\mathrm{Si}: \mathrm{H}, \mathrm{Gl}$ ) and the first observation of chlorine related bands. We discuss their origin and infer that chlorine acts as a dangling bond terminator. The thermal stability of hydrogen and chlorine was investigated from annealing experiments.

Preparation of a-Si:H, Cl films:

Samples with thickness of $1 \mu \mathrm{m}$ were prepared on crystalline silicon wafers by glow discharge of a silicon tetrachloride ( $\mathrm{SiCl}_{4}$ ) and hydrogen mixture. The substrates were held at about $280^{\circ} \mathrm{C}$. The power level was 0.2 watt $/ \mathrm{cm}^{2}$ and the growth rate $3 \mathrm{~A} / \mathrm{s}$. Our films contained 6 to $7 \%$ atomic chlorine as determined from electron microprobe analysis and 5\% atomic bounded hydrogen as we shall see further. More information on the preparation conditions and properties of the films will be published elsewhere $L \overline{5} \bar{l}$.

\section{Absorption spectra :}

Figure 1 shows a typical infrared spectrum of a a-Si: $\mathrm{H}, \mathrm{Cl}$ $\mathrm{film}$ in the range $4000-200 \mathrm{~cm}^{-1}$ recorded with a PERKIN-ELMER 683 spectrophotometer. The hydrogen induced bands are identified by comparison with purely hydrogenated amorphous silicon $/ \overline{6} /$ :

Fig. 1 - Typical infrared spectrum of a a-Si:H,Cl sample.

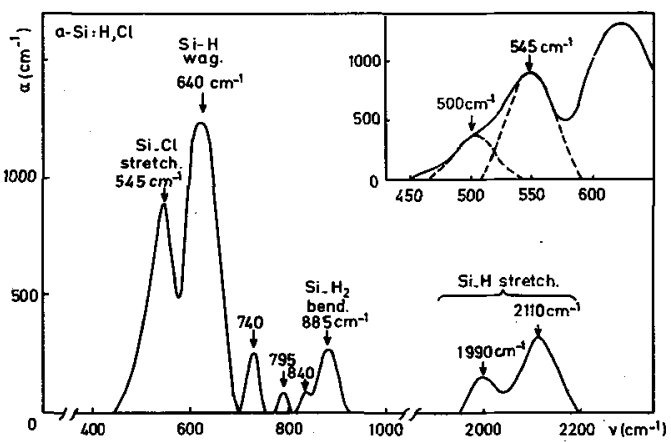


they are successively attributed to stretching modes of $\left(\mathrm{SiH}_{2}\right)_{\mathrm{n}}$ and $\mathrm{SiH}_{2}$ groups $\left(2110 \mathrm{~cm}^{-1}\right)$, stretching modes of SiH groups $\left(1990 \mathrm{~cm}^{-1}\right)$, bending modes of $\mathrm{SiH}_{2}$ $\left(885 \mathrm{~cm}^{-1}\right)$ and $\left(\mathrm{SiH}_{2}\right)_{\mathrm{n}}\left(840 \mathrm{~cm}^{-1}\right)$ and wagging-rocking modes of $\mathrm{SiH}$ and $\mathrm{SiH}_{2}$ species $\left(640 \mathrm{~cm}^{-1}\right)$. The bands at $740 \mathrm{~cm}^{-1}$ and $795 \mathrm{~cm}^{-1}$ are not reported in a-si:H literature. Their origin is not clearly established.

Two modes appear at low energy. The main band, located at $545 \mathrm{~cm}^{-1}$, has not been reported until now. We rule out the possibility of chlorosilane molecules $\mathrm{SiCl}_{\mathrm{n}} \mathrm{H}_{4-\mathrm{n}}(1 \leqslant \mathrm{n} \leqslant 4)$ indembbed in the matrix because either the Si-C1 stretching mode frequencies of these molecules are too far from this value or their Si-H stretching modes are not visible in our infrared spectra. In figure 2, we present the $\mathrm{S} \hat{1}-\mathrm{C} 1$ stretching frequency dependences of a number of

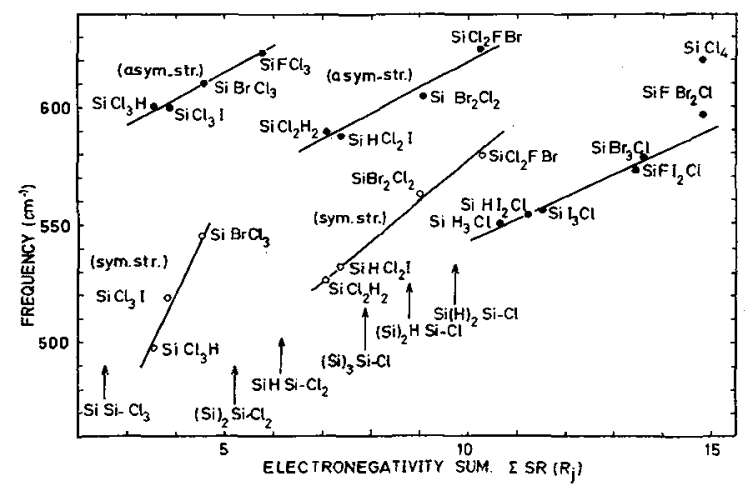

Fig. 2 - Variation of the Si-Cl stretching modt frequency versus the electronegativity sum of substituted elements in various chlorosilane molecules.
SiCl $\ln _{n}$-n molecules with the SANDERSON's electronegativity sum of $X_{4-n}$ atoms $(X=F, I, B r, H)$. These frequencies cover a range from $621 \mathrm{~cm}^{-1}$ ( $\mathrm{SiCl}_{4}$ ) to $498 \mathrm{~cm}^{-1}$ $\left(\mathrm{SiCl}_{3} \mathrm{H}\right)$. The arrows indicate the electronegativity of various configurations involving one, two or three chlorine atoms bounded to the same silicon atom. We clearly see that he $545 \mathrm{~cm}^{-1}$ frequency falls within the corresponding range. This result suggests that the $545 \mathrm{~cm}^{-1}$ band in related to a $\mathrm{Si}-\mathrm{Cl}$ stretching vibrational mode with a chlorine aiom forming a single bond with silicon. This is the first observation of chlorine acting as a dangling bond terminator in a hydrogenated amorphous silicon matrix.

The band at $500 \mathrm{~cm}^{-1}$ appears as a tail of the main band at $545 \mathrm{~cm}^{-1}$ (see insert of Fig.1). Without discarding the presence of some Si-C1 symetric stretching mode due to a different configuration, we attribute this band to a To optical phonon of the amorphous silicon matrix. Because of its large electronegativity, chlorine induces a charge transfer in its neighborhood. As a consequence, infrared inactive mode of non polar silicon becomes activated in chlorinated amorphous silicon.

\section{Annealing experiments :}

Isochronal annealings have been performed on a series of samples. Films were heated for 45 minutes in a purified $\mathrm{H}_{2}$ flow. The hydrogen bands remain constant up to $320^{\circ} \mathrm{C}$ and then decreases rapidly (Fig. 3). The behaviour of the $2110 \mathrm{~cm}^{-1} \mathrm{stret-}$ ching mode with annealing is quite different from that of the $885 \mathrm{~cm}^{-1}$ bending modes of $\mathrm{SiH}_{2}$ groups. Hence, this band is partly due to species other than $\mathrm{SiH}_{2}$. The SiH stretching frequency is known to depend on the electronegativity of substituted species. Following LUCOVSKY $/ \overline{7}$, we can estimate that the SiH stretching frequency in SiHCl and SiH H Cl configurations will be respectively 2100 and $2140 \mathrm{~cm}^{-1}$. Consequently, we think that these species probably contribute to the $2110 \mathrm{~cm}^{-1}$ absorption band.

The Si-Cl stretching band decreases also above $320^{\circ} \mathrm{C}$ but relatively more slowly than most of hydrogen induced bands. An interesting feature of this band is shown in the insert. Its corresponding frequency continuously shifts from $545 \mathrm{~cm}^{-1}$ to $578 \mathrm{~cm}^{-1}$ as the annealing temperature increases from 260 to $600^{\circ} \mathrm{C}$. This effect suggests a change in the configuration involved in the Si-CI stretching mode. Such changes have been observed in purely a :Si-H $/ \overline{8} T$ and interpreted as the result of Si-H bonds in acluster of four, pointing towards the equivalent of a crystalline silicon vacancy. Because of the large size of chlorine atoms, we think that such clusters are unlikely. Figure 2 shows that the stretching mode frequency increases as 


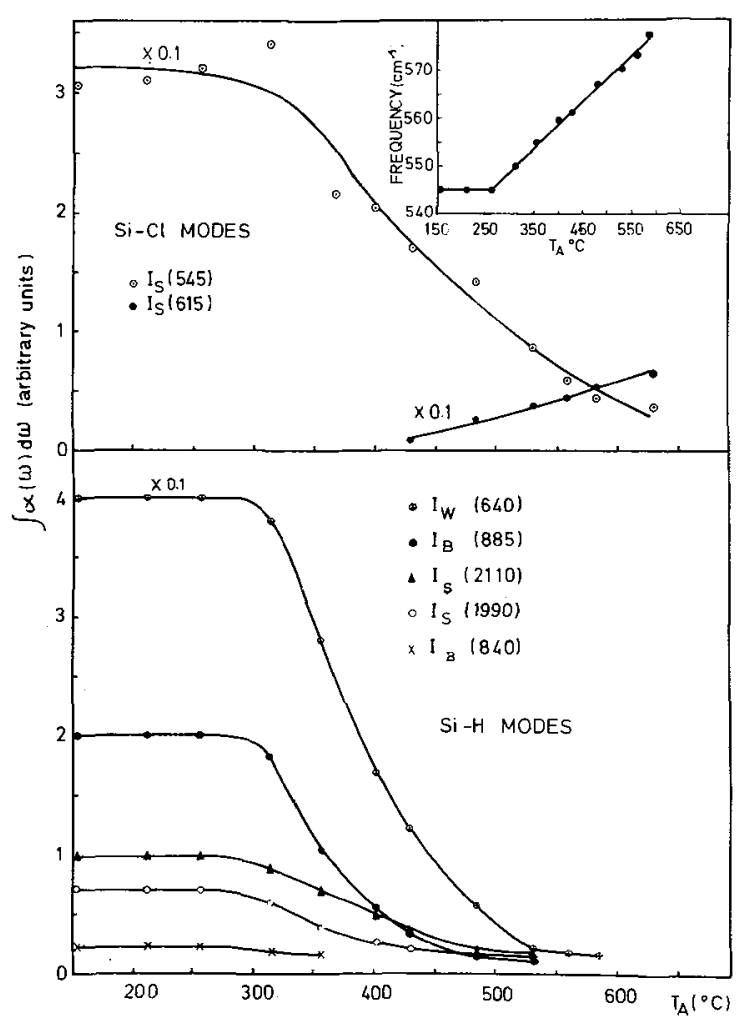

Fig. 3 - Integrated absorption variation of the $\mathrm{Si}-\mathrm{Cl}$ and $\mathrm{Si-H}$ induced bands versus the annealing temperature. silicon is replaced by hydrogen or chlorine atoms in the various possible configurations around a given silicon atom. We suggest that in unannealed samples, the dominant configurations are SiHCl or (and) SiH H Cl. As the temperature increases, hydrogen and chlorine are released from such configurations which would favor the formation of $\mathrm{SiCl}_{2}$ and $\mathrm{SiCl}_{3}$ types of configurations. Such a view is supported by the following experimental fact. Above $400^{\circ} \mathrm{C}$, a new band located at $615 \mathrm{~cm}^{-1}$ appears in our infrared spectra. It is interpreted as the asymetric Si-Cl stretching mode of $\mathrm{SiCl}_{4}$ molecules formed in the matrix during annealing. Formation of $\mathrm{SiF}_{4}$ molecules have also been observed in annealing experiments of $\mathrm{a}-\mathrm{Si}: \mathrm{H}, \mathrm{F}$ samples $I \overline{9} \bar{T}$.

Bounded chlorine and hydrogen concentrations :

By using an oscillator strength value of $16 \mathrm{~cm}^{2} / \mathrm{mmole}$. bond deduced from published absorption data of various chlorosilane gases and local field corrections given by 3RODSKY $/ \overline{10} /$, we found $8 \%$ atomic bounded chlorine from the integrated $\mathrm{Si}-\mathrm{Cl}$ absorption band at $545 \mathrm{~cm}^{-1}$. This is in good agreement with the $6-7 \%$ determined from electron microprobe analysis. The concentration of bounded hydrogen has been calculated from the integraded absorption of the $\mathrm{Si}-\mathrm{H}$ wagging band at $540 \mathrm{~cm}^{-1} / 8 \%$. A value of $5 \%$ atonic has been found.

\section{Conclusions :}

From the observation of the Si-Cl stretching mode in i.r. absorption, we have established that chlorine is able to compensate the dangling bonds as fluorine and hydrogen do.

\section{References :}

T1 T - SPEAR W.E., LE COMBER P.G. - Phil. Mag. 33 (1976) 935.

I 2 I - CARLSON D.E., WRONSKI C.R. - App1. Phys. Lett., 28 (1976) 671.

$7-37$ - SHIMADA T., KATAYAMA Y. - Jap. J. of App1. Phys., 19 (1980) L 265.

$7-\frac{7}{7}$ - MADAN A., OVSHINSKY S.R. - J. Non-Cryst. So1., 35- $\overline{36}$ (1980) 171.

$7 / 5-7$ - CHEVALlier J., KALEM S., AL DALLAL S., BOURNEIX J. - to be published.

7 - LUCOVSKY G., NEMANICH R.J., KNIGHTS J.G. - Phys. Rev., B 19 (1979) 2064.

$77^{-T}$ - LUCOVSKY G. - Sol. St. Com., 29 (1979) 571 .

I 8 - SHANKS H., FANG C.J., LEY L., CARDONA M., DEMOND F.J., KALBITZER S. - Phys. Stat. Sol, , 100 (1980) 43.

I 9 I - FANG C.J., LEY L., SHANKS H.R., GRUNTZ K.J., CARDONA M. - Phys. Rev. B 22 (1980) 6140

I10_t - BRODSKY M.H., CARDONA M., CUOMO J.J. - Phys. Rev. B 16 (1977) 3556. 